Article

\title{
Growing Green and Competitive-A Case Study of a Swedish Pulp Mill
}

\section{Kristina Söderholm $^{1{ }^{*} *}$ and Ann-Kristin Bergquist ${ }^{2}$}

1 History of Technology Unit, Luleå University of Technology, SE 97187 Luleå, Sweden

2 Department of Geography and Economic History, Umeå University, SE 90187 Umeå, Sweden

* Author to whom correspondence should be addressed; E-Mail: kristina.soderholm@1tu.se;

Tel.: +46-920-491-541; Fax: +46-920-491-399.

Received: 28 January 2013; in revised form: 4 April 2013 / Accepted: 22 April 2013 /

Published: 29 April 2013

\begin{abstract}
The experiences of past efforts of industrial pollution control while maintaining competitiveness should be of great value to research and policy practice addressing sustainability issues today. In this article, we analyze the environmental adaptation of the Swedish pulp industry during the period 1970-1990 as illustrated by the sulfite pulp producer Domsjö mill. We investigate how this company managed to adapt to heavy transformation pressure from increasing international competition in combination with strict national environmental regulations during the 1960s to the early 1990s. In line with the so-called Porter hypothesis, the company was able to coordinate the problems that were environmental in nature with activities aiming at production efficiency goals and the development of new products. Swedish environmental agencies and legislation facilitated this "win-win" situation by a flexible but still challenging regulatory approach towards the company. From the early 1990s and onwards, the greening of the pulp industry was also a result of increased market pressure for green paper products.
\end{abstract}

Keywords: pulp and paper; porter hypothesis; Sweden; history

\section{Introduction}

For at least the past 50 years, Western countries have made serious attempts to deal with severe pollution problems related to industrial production. At the same time, industrial production has formed the core of their wealth in terms of employment and export revenue. Thus, it has been a major 
challenge for policy makers to design legislation and practices that can achieve the highest possible environmental improvements while taking into account the international competitiveness of enterprises. Sweden was fairly successful in comparison with other western countries in improving the environmental quality in the 1970s and 80s [1]. The Swedish pulp and paper industry accomplished especially comprehensive reductions over this period, up to $90 \%$ of, among other things, chemical oxygen demanding substances [2]. Moreover, Sweden is recognized as having led the market for non-chlorine pulp, which emerged at the end of the 1980s [3]. In this article, we adopt a case study approach to explore the long-term experiences of business transforming towards greener production processes within the context of the Swedish institutional setting for environmental protection from the late 1960s to the 1990s. During this period, the Swedish pulp producers faced a strong regulatory pressure in combination with increasing international competition. Moreover, at the turn of the 1980s, a strong consumer demand emerged for chlorine-free pulp. The case used in our study is a Swedish pulp mill, Domsjö sulfite mill (hereinafter referred to as "Domsjö"), owned by a Swedish multinational forest industry MoDo. In the late 1960s, Domsjö was well known for serious environmental problems, especially since the plant was located on a bay, close to a city and residential areas. While facing threats of market exit due to the combination of fierce international competition and the high environmental standards required by the authorities, the company managed to reconstruct their business over a 20-year period. The company not only cut emissions substantially, but also incrementally developed process technology which enabled the introduction of a specific quality of total chlorine free bleached pulp (TCF) on the market. By studying this transformation, we hope to contribute with historical lessons of "black boxed" processes related to how regulation and markets influence companies long-term ability to advance new technology and transform towards more sustainable production processes.

\subsection{Environmental Regulation, Technology Development and Firm Competiveness}

Technology is the core when it comes to firm strategies, both regarding reducing environmental impacts and accomplishing competitiveness. These processes are further influenced by the regulatory approach under which the firm operates. Clearly, the environmental regulative approach differs between countries. While the regulatory frameworks of some countries have given industry both the freedom and the incentives to pursue innovative responses to environmental challenges, it has been less successful in recognizing either the necessity or the conditions required for innovation in others [4]. According to the environmental economics literature, a strict environmental policy always imposes costs for firms and thus impacts on their competiveness, something that in the end will imply negative societal economic impacts, including lower employment rates [5]. This traditional view was however challenged in the early 1990s, by the seminal works of Michael E Porter, who suggests that there might be a "win-win" situation due to the dynamic effects caused by pressure induced by environmental regulations [6,7]. Porter and van der Linde [7] argue that environmental regulation can make firms realize new opportunities for improved productivity and efficiency (there are more recent updates in empirical and theoretical contributions on the topic $[8,9]$ ). The pressure from a strict and properly designed environmental regulation might, according to this line of reasoning, foster innovative solutions that fully or partly mitigate environmental investment costs. The important thing in Porters 
view is to create an environment with maximum opportunity for innovation, leaving the approach to innovation to industry and not the "standard-setting" agency. Second, regulations should foster continuous improvement rather than locking-in any particular technology, and third, the regulatory process should leave as little room as possible for uncertainty at every stage. Moreover, regulations should encourage product and process changes to better utilize resources and avoid pollution early, rather than mandating end-of-pipe or secondary treatment, which is almost always more costly. Porter and van der Linde [7] therefore argue that: "Where possible, regulations should include the use of market incentives, including pollution taxes, deposit-refund schemes and tradable permits" [7] (p. 111). However, it has been argued that the assumption (as reflected in the quote above) that "command-andcontrol" regulation - the alternative and traditionally used regulation - constitutes a constraint to innovation, is based on the U.S. experience where "standard-based" regulation have most often resulted in end-of-pipe innovations [10].

There is an extensive literature on the innovation effects of different types of environmental policy instruments. Much of this earlier work is of theoretical nature [11] and essentially shows that there exist a number of different outcomes contingent on particular assumptions about, for instance, the degree of competition in the output market, the characteristics of the relevant environmental damages, the timing and commitment strategies available for the regulator, and the uncertainty about future abatement costs etc. It is therefore overall virtually impossible to present a unanimous ranking of policy instruments with respect to their innovation-stimulating effects [12]. Additional research, both theoretical and empirical, is thus needed to explore which policy instruments, and under which conditions, can contribute to innovations and the adoption of new technology. This article addresses whether the Swedish regulatory approach imposed an opportunity structure for the presence of "Porter effects" and thus facilitated the transformation process of Domsjö in the 1970s and 80s. Guiding questions for the analysis will thus e.g., be: Did, and in that case how did the environmental regulation bring to light inefficiencies in the production process that had not been brought attention to in the past?, and; Did, and in that case how did the regulation induce innovation in the firm that improved the company's competitive situation?

\subsection{Motivation of the Case, Method and Structure of the Paper}

Domsjö used the sulfite method for producing chemical pulp, while the lion's share of the Swedish pulp industry produced kraft pulp (according to the sulfate method). The new environmental regulation implemented in Sweden in the late 1960s contributed to a phase out of almost all sulfite pulp mills in Sweden. Domsjö was one of few sulfite mills that succeeded in "greening" and stay on the market despite expected drawbacks of the process. Domsjö therefore represents an apt case to study the dynamics of green innovation processes. The case study analysis as such allows us to study the dynamics of policy implementation and industry responses at greater depth than, for instance, econometric and survey-based approaches. Thus, it will allow us to shed light on how choices have been made in situations of uncertainty and mutual influence between the firm and the regulator. This complements the existing case study literature that comprises a number of interesting studies on industrial pollution control, either addressing the overall characteristics of a country's regulatory approach and/or focusing on the environmental compliance and innovation activities of a specific 
company or industry sector following the implementation of regulations [13,14]. In the present study, particular attention will be paid to: (i) the regulatory requirements; (ii) the R\&D activities as a response to the regulatory pressure; and (iii) to what extent and under which conditions long-term goals and R\&D activities were coordinated between problems that were environmental in nature with activities aiming at production efficiency goals or new products. The case is limited to environmental problems related to emissions to water, which were the most critical, research intensive and costly problems to solve for the firm.

When it comes to earlier works of the long-term development of the Swedish pulp and paper industry, rather little attention have been paid to the impact of the environmental issue, but instead typically focus on strategy formation/development, market integration, organizational changes and changing ownership structures within the line of business [15-19]. There are, however, recent exceptions which point to a collaborative strategy within the Swedish pulp and paper industry to comply with the environmental requirements since the late 1960s, and a regulatory approach with built-in flexibility in compliance strategies and which further favored internal process changes over end of-pipe solutions [20-22]. These strategies contrast heavily to the North American system, where the primary paradigm for pollution-control policies was uniform, technology-based guidelines for comparable plants in the pulp and paper industry.

The source material underpinning our study is mainly based on company board minutes, annual reports and archive materials from the lengthy licensing process under the Environmental Protection Act (EPAct) that the company was involved in during the 1970s and 80s. Beyond that, source material consists of a couple of company monographs [23,24]. In addition, to verify some questions of technological character we interviewed the former (active during the studied period) environmental manager at Domsjö [25]. Our understanding of the regulatory practice is further based on our previous research where we have conducted a number of interviews with officials of the environmental authorities as well as with consultant companies and business managers. Detailed source references are available in previous articles and working papers $[20,26]$. The proceeding of our paper is structured as follows. Section 2 below comprises of an overview of early modern environmental legislation in Sweden and the development of the Swedish pulp and paper industry and MoDo/Domsjö up to the 1960s. This is, in Section 3, followed by a narrative illustration of the long-term strategies and prerequisites of Domsjö and its company MoDo, to comply with the enforcements of the EPAct and parallel increasing international competition in the 1970s to the early 1990s. In the concluding Section 4 of the article, the most important strategies and prerequisites are summarized and central implications discussed in order to enrich our understanding of the greening of industries.

\section{The Modern Environmental Legislation and Pulp Industry in Sweden: A Short Background}

\subsection{Early Modern Environmental Legislation in Sweden}

The EPAct (1969) represented the first uniform framework for regulation of emissions to air, water pollution, noise and other disturbing activities from industrial plants in Sweden. The Act was based on case-by-case licensing of polluting plants; firms had to have their plans for the construction or alteration of production plants assessed according to several criteria specified in the Act. The licensing 
system was administrated by the so-called Franchise Board of Environmental Protection (FBEP). The regulatory approach was based on performance rather than on technology standards, and these were negotiated with each plant owner, sometimes over extended periods of time. This granted flexibility to firms in terms of selecting the appropriate compliance measures. Statements submitted by the Swedish Environmental Protection Agency (hereafter SEPA) were furthermore also to be considered by the FBEP in each case. As a general rule, the industrial polluters were required to take all precautionary measures and tolerate such restrictions on their activities as could be reasonably demanded [27].

In specifying the performance standards, the FBEP was initially aided by a system of national emission guidelines. These contained recommendations concerning the maximum allowable emissions of certain types of pollution from specified classes of stationary sources, and they were elaborated during the late $1960 \mathrm{~s}$ by a joint panel of government- and industry experts [28]. The intense cooperation between the regulators and the polluters in establishing these guidelines was, according to Lundqvist [29], an expression of a special style of Swedish regulatory approach. A major vehicle for this regulatory approach was the transfer of information among firms, government authorities and research institutes. Rational decisions could, it was perceived, only be reached if each of the parties knew exactly what the other wanted and why [28]. A central feature of the system was further that changes in internal processes designed to reduce emissions were favored over end-of-pipe solutions - a technological strategy which in turn was enabled by the performance based regulation approach [21]. Another typical feature was that new knowledge was advanced incrementally in interaction between the company, the environmental authorities and research institutions. When it comes to the environmental compliance of the Swedish pulp and paper industry, this knowledge advancement by interaction often took place within large R\&D projects. In the ways described, the Swedish regulatory approach provided scope for creative solutions, environmental innovation, and permitted the affected companies to coordinate pollution abatement measures with productive investments $[20,21,30]$.

\subsection{The Development of the Swedish Pulp and Paper Industry and MoDo/Domsjö up to the 1960s}

Pulp and paper production started on a larger scale in Sweden in the end of the $19^{\text {th }}$ century and formed an important component of the Swedish industrialization. In its initial phase, the industry sector was typically dominated by small paper mills, often with integrated production of pulp and paper. As demand for paper grew stronger, a large number of saw mill companies established in the northern part of Sweden started to produce pulp. The production in the north was designed for export on the international market, such as the U.S., Great Britain and Germany [31]. The major player in the north region was MoDo, a company owned by the Kempe family who as far back as in 1779 started a small saw mill business and later, in the years of 1902-03, established a sulfite pulp mill in Domsjö, close to the northern town Örnsköldsvik. In an initial phase, Domsjö had the capacity to produce 6000 tons of calcium-based sulfite pulp, but in time for the Second World War the production capacity had expanded to 80000 tons per year. In the 1960 s, MoDo had grown into a multinational company engaged in forestry, sawmill industry, chemical industry and, at the heart of the business, pulp and paper production. In addition, after the structural rationalizations and the concentration of ownership within the industry sector during the 1970s and 1980s, MoDo was one four major forest companies in Sweden that remained [23]. 
Sales of pulp were totally dominating for the business of MoDo over the second half of the 20th century, which implied a vulnerability to competition and price changes on the world market. In the 1960 s, the domestic price of wood was increasing in relation to the competing countries, which put a pressure on the Swedish pulp producers, including MoDo, to cut their production costs. At the same time, the U.S. market, which earlier counted for one third of MoDo:s exports, had more or less disappeared due to competition from the North American producers. Moreover, U.S.- and Canadian producers expanded on the European market which put additional pressure on the Swedish producers to cut their costs.

Concerning the Swedish economy in general, signs of economic recession emerged in the mid-1960s due to increasing international competition. As a response, MoDo as well as other large Swedish forest companies were forced to employ new strategies to increase scale and diversify the production to reach new (and more stable) markets [23]. This included big investments in R\&D, marketing and new machinery. The crisis was however also structural in its character [32-35] and called for a concentration of pulp and paper production into larger units. The number of Swedish pulp plants decreased from 110 to 35 between 1960 and 1980, while production increased by 74 percent [36]. The concentration involved the shut-down of inefficient plants, of which many were sulfite pulp mills. The phase out of calcium-based sulfite pulp mills was due to their many environmental disadvantages in terms of discharges of BOD, lignin, gases and dust, which required radical external purification works that often went far beyond what was economically justifiable. Pulp producers therefore strategically aimed for production expansion based on the adoption of the sulfate process, which apart from being less polluting than the sulfite process had the potential to recover chemicals and at the same time generate electricity [37].

The trend of concentrated pulp and paper production from the 1960s has been recognized as an implicating factor for the parallel improved pollution control, where the phasing-out of calcium-based sulfite pulp mills is a good example [37,38]. The Swedish pulp and paper producers invested heavily to curtail environmental problems in the 1970s and 80s. Over this period, the costs for environmental investments, based on the Swedish forest industry's questionnaire data, accounted for 9-14 percent of total industry investments. The investments rendered significant emission cuts, such as of Chemical Oxygen Demand (COD), which decreased from approximately 2.3 to 0.4 million tons annually over the period 1970-1995 [39]. Söderholm and Bergquist [20] have shown that an important part of the emission reductions was made possible through extensive environmental R\&D efforts within industry-wide collaborative platforms established by the pulp and paper industry in the 1960s. Because the sulfate (kraft-) pulp industry dominated the production expansion, the collaborative R\&D efforts would come to focus on process technology of importance to sulfate producers.

In the following, we will focus on the "black-box" processes related to the greening of Domsjö: a case with specific and challenging processes technology from an environmental point of view. By following the transformation over more than 20 years, we will explore company strategies to comply with the enforcements of the EPAct and parallel increasing international competition in the 1970s to the early 1990s. We will portray this transformation in a narrative, historical context, and the circumstances leading the technology development forward. Detailed source references for Section 3 are available in a previous working paper [26]. 


\section{Domsjö Sulfite Mill and the Environment, the 1970s to the early $1990 \mathrm{~s}$}

In 1971, MoDo took the decision to expand the capacity at Domsjö. The decision was consistent with the company's ambitions to invest its way out of the crisis, the latter caused by falling pulp prices as well as the transformation of the U.S. from a leading export market to a leading competitor. With this decision came the filing of an application with FBEP, and as a key strategy to reduce discharges, the company emphasized the decision to invest in sedimentation basins at Domsjö. The basins were constructed and in process already in 1972, and had the capacity to return 1,000 tons of fiber to production. At this stage, it is possible that the company thought that this "environmental investment" was adequate. Even though Domsjö suffered from severe pollution problems, the mill was not one of the most polluting sulfite pulp producers in Sweden. Only a few years earlier the company had made investments in improved black liquor and sulfur recovery, which had reduced discharges heavily. This had partly been achieved in 1959, through the switch to sodium base over calcium base. In addition to recycling black liquor and sulfur, the sodium base in contrast to the calcium base enabled the utilization of pinewood in the production process, and this was critical due to the large amounts of wood required for the viscose pulp produced at Domsjö. Increased sulfur recovery had furthermore been received through flue gas washing with scrubbers where an important driver was the recovering of heat from the flue gases. After having tested the devices on a lab scale, the first scrubber was installed at Domsjö in 1963. Within this context, the most important condition to meet future environmental requirements was the switch from calcium to sodium base in 1959, which gave the company important advantages, both economically and environmentally.

Contemporary to the construction of the sedimentation basins in 1972, a statement by the technical director at MoDo, Axel Scholander, illustrates how the environmental issue was perceived at the company. The statement concerned the central conditions and developments that were ahead for the pulp and paper industry in the 1970s, and reflects how the environmental issue was perceived as indeed having serious and long-term impacts on the business development, such as the possible decline of the sulfite industry. The statement however also tells us something about the Swedish culture at the time, the "Swedish Model", with policy processes based on compromises and consensus-seeking procedures with little conflicts between the industry and the state authorities. It furthermore includes early wordings on the interrelated mechanisms of green products and the market.

"The environmental protection deliberations, referring to the natural environment — water, air, noise, ecological disruptions - have primarily taken place among young people and politicians. The fears about mankind's future living environment and the genetic legacy are so strong that counter arguments of an economic nature will never be accepted - although it may be possible to permit economic realities to influence the pace at which environmental protection efforts are introduced. We are going to experience a global movement in this area because it is essentially politically non-partisan and must be accepted by all politicians worldwide. It will become as politically absurd to oppose environmental protection as it would be to oppose health care, elderly care, retirement pensions, or measures to reduce unemployment." 


\section{Concerning MoDo, Scholander continued:}

“The environmental protection element of MoDo's investments is something we are expecting to increase and preferably — if we can manage it — with at least five years' advance planning ahead of more rigorous government standards. This is going to impact our "productive" build-up rate.

Environmental protection aspects may also lead to restructuring on both the production and consumptions sides: to the decline of the sulfite pulp industry (Here Scholander refers to the serious water and air pollution problems of the sulfite industry, "that can only be prevented through high capital and operating costs that squeeze out sulfite in favor of kraft") [and to] high retooling costs in the kraft pulp industry to avoid odor problems and water pollution (Here Scholander refers to sulfur-free cooking and oxygen bleaching). This may bring positive effects on the consumption side because cellulose materials are easily biodegradable and thus environmentally friendly."

The processing of the application to the FBEP would take time-the first partial decision on emission limits was not announced until the year 1980 - and the company board noted in the mid-1970s that the postponing of the expansion due to the delayed application process made the basis for planning unwieldy. It would, however, quite soon come clear to the company that the sedimentation basins were far from adequate "environmental investments" and MoDo therefore carried through relatively comprehensive environment-related R\&D in the 1970s, partly on the encouragement and even direct request of authorities (see below). The company in parallel invested in a number of emission reduction measures at Domsjö. These investments were partly made possible through governmental subsidies issued in the 1970s, for investments in environmental protection "due to the prevailing cyclical employment". In 1971 the MoDo board had taken the decision to apply for such subsidies "to the greatest extent possible."

\subsection{The SEPA Approach}

SEPA adopted a tough approach through the application process. This was linked to the company's discharge area, the Örnsköldsvik Bay, which in turn is connected to the Baltic Sea. This implied two challenges. First, SEPA was committed to the 1974 Convention on the Protection of the Marine Environment of the Baltic Sea Area. Second, the Örnsköldsvik Bay itself bore a heavy recipient load. SEPA referred to the above as the short-term aspects of the problem and pointed out that there was also a long-term aspect connected to the toxic substances found in the wastewater discharges from the bleach plants of the pulp industry which currently (in 1975) were being studied in a joint project among the Nordic countries. SEPA stated that it was not yet clear what effects these waste discharges had, but it was possible that they influenced vital processes and might accumulate in organisms. What we witness here is the opening salvo of the debate on the toxic effects of bleach plant wastewater that would ultimately culminate in the dioxin scare 10 years later.

In commenting on the measures needed to treat the wastewater so that the toxic part of the whole could be removed, SEPA established (in 1975) that these probably not would be carried out before the year 1980. SEPA would therefore not yet specify any proposals for conditions, but nevertheless argued that the company should be obliged to continue its efforts to develop methods for treating its wastewater. In this context, SEPA argued heavily in favor of external treatment of bleach plant wastewater and for investing in a biological waste treatment plant. A SEPA representative commented 
on the fact that the agency was in favor of an external rather than an internal measure: "We [SEPA] believe we have taken the right initiative in Sweden by concentrating on internal measures. [...] but I am also convinced that it will not lead to a total solution to the problem." MoDo in turn advocated internal measures. The company had a long tradition of in-house R\&D on the internal process, and not the least on the bleach plant process.

\subsection{In-House $R \& D$ at MoDo}

The R\&D activities at MoDo's three pulp mills were decentralized until the 1940s and supported by small operational labs, although development work often took place on a plant scale. Early on production at Domsjö was oriented towards specialty pulp qualities, with particular interest devoted to the production of viscose pulp. The viscose pulp puts greater demands on the manufacturing process than other pulp qualities and R\&D was needed for control and development. Hence, R\&D efforts were extensive at the Domsjö unit. At one of the company's other pulp mills, Husum, attempts to use birch wood as a raw material in the kraft process began in the 1940s. Since bleaching with chlorine dioxide was one of the prerequisites for attaining this goal, development efforts were initiated at the R\&D lab in the early 1940s to produce the new bleaching agent chlorine dioxide. The development work proved fruitful and the Husum bleach plant was equipped for chlorine dioxide bleaching in the late 1940s, and was followed by Domsjö just a few years later. This was a method that three or four decades later would come to play a key role in the environmental adaptation process, mainly since chlorine dioxide bleaching reduced the AOX and dioxin load in wastewater relative to chlorine bleaching.

By the early 1950s, the company's R\&D became centralized to the Domsjö area, with about 70 employees in shared premises with laboratory space and for tests on a semi-technical scale. And during the late 1960s, R\&D was oriented towards another bleach plant process - the oxygen bleaching technique - which saved half the chlorine and sharply reduced discharges of organic substances from the bleaching process. This was not an entirely new technique, but MoDo, working together with the chemical manufacturer, Canadian Industries Ltd, and the machinery manufacturer, Sunds AB, played a significant role in developing the technique to make it useable on a plant scale. For various reasons, the first full-scale oxygen bleaching system was not built at any of the company's mills, but rather at ASPA in 1973. MoDo's R\&D staff, however, made strong contributions to putting the ASPA system into operation. In 1977, oxygen bleaching was introduced at the MoDo mill Husum and eventually at Domsjö as well.

Even if the first partial decision on emission limits was not announced until the year 1980, the MoDo board noted in the mid-1970s that SEPA was successively increasing its demands through its constant interaction with the company. Thus, in 1973/1974, SEPA e.g. made it clear for MoDo that the agency could not approve the expansion of Domsjö without more comprehensive measures than had thus far been taken. Among else, SEPA recommended that the wash effect after the cooking plant needed to be immediately raised to $96 \%$ whereupon the company performed cost/benefit analysis and applied for government subsidies for investments in filter washing. SEPA approved a grant of more than 40 percent of the cost and parts of the project were in test operation 18 months later. The MoDo board found the public subsidy as essential to the investment. 


\subsection{MoDo Was Imposed to Study Biological Wastewater Treatment}

In April 1976, FBEP ordered the company to study biological treatment of all polluted wastewater from the mill in accordance with SEPA's suggestions. The company was, however, also required to study opportunities to further reduce the discharges of chlorine-containing bleach plant wastewater, and this opened up for internal measures. That same spring, the company invested in an entirely new bleach plant at the mill, which significantly reduced the emissions of chlorine-containing wastewater from the bleach plant (bleach plant discharges could be halved by changing the order of the bleaching stages). Still, the company continued to study in lab scale how, for instance, a higher admixture of chlorine dioxide in the chlorine stage affected the quantity of released environmentally destructive substances, and how changes in bleaching frequency combined with partial closure of the stages affected brightness from bleaching, chemical consumption, and the environment.

When it comes to biological treatment of wastewater, the company had already in 1974 commenced tests together with a Swedish consultancy firm, Vattenbyggnadsbyrån, to treat wastewater from the sulfite mill together with municipal wastewater in the nearby municipal treatment plant. Full-scale tests were initiated after the FBEP decision in 1976. During the test period, problems however arose with sludge that was difficult to dewater. The management of the municipal treatment plant argued that these problems were caused by the wash water from the mill and the municipality subsequently refused to permit further tests. In parallel with these tests, the company was also testing biological treatment on a lab scale in cooperation with an engineering firm, Orrje \& Co. These tests showed that the studied wastewater was biodegradable, but that treatment was impossible in an aerated pool because there were no sufficient land areas available and due to the high BS content of the water. Instead, the company stated in a 1978 report to FBEP that it might be possible to perform the biological treatment using the Deep Shaft method, where the biodegradation takes place under high hydrostatic pressure in a shaft in the ground at about 100 meters depth. The company had studied the method in cooperation with the British chemical group "Imperial Chemical Industries", but adequate testing had not yet been performed and the technical conditions were thus still uncertain.

And then, in 1979, the company, instead of commencing further tests on various biological treatments offered to further study the possibility of reducing wastewater emissions through internal measures, such as from the bleach plant where almost half of the mill's total discharges of BOD $^{7}$ were released. The fact is that the company at this time made a serious and in-depth attempt to argue against the investment in a biological treatment plant, including by referring to the annual cost for a similar plant, which the company claimed was SEK 12 million or equal to the cost (wages and social security contributions) for 120 full-time workers for one year.

The company had reason to oppose expenditures of this magnitude. The market situation was strained and new environmental- and energy policy put even more pressure on the Swedish producers to carefully weigh investing activities. In the fall of 1977, the company's president noted that the market situation had forced the Scandinavian pulp industry into further price reductions. And in the spring of 1978, the company board established that long-term investing activities in the 1980s, beyond the requirement for profitable processing of the wood raw material, must also carefully consider the company's responsibility for its employees, public environmental protection standards, and the adopted energy policy. When the company had truly entered the 1980s a couple of years later, the 
board of directors determined that the investment plan for the 1980s should also have taken into account a number of preconditions of a risk nature, such as: (A) rapid economic downturns; (B) much steeper energy prices; (C) inconsistent wood supply; and (D) stronger demands for environmental protection investments. In the end of the 1970s, the MoDo board furthermore noted that Domsjö had not generated acceptable earnings for much of the 1970s and actually made a loss in the final years of the decade. Still, environmental protection investments at the mill mounted up to SEK 100 million (including about SEK 20 million in government subsidies) over the period 1971-1978, calculated from 1979 monetary values (about USD 60 million in today's money value). The company noted that environmental protection costs were higher for the Swedish paper and pulp industry than for the Finnish and Canadian industries, although lower than for the American: "However, the higher costs of environmental protection in the U.S., at SEK 30-50 per ton of pulp, are more than offset by the lower cost of wood in the U.S."

\subsection{The License of 1980 and the Successful Anamet Method}

In March 1980, the company finally obtained a license from the FBEP. This contained the condition that such measures were taken by July 1, 1983, that discharges of BOD $^{7}$ from the mill (excluding the final bleaching) did not exceed an annual average of six tons per day. These were, to put it mildly, tough conditions that ultimately would require investment in a biological treatment plant. The issue of final conditions for discharges of bleach plant wastewater was postponed in the 1980 decision, but the company was required to continue studying opportunities to replace elementary chlorine with chlorine dioxide or otherwise change the bleaching process to reduce discharges.

After FBEP's decision in 1980, MoDo applied for, and was granted in total, two-years extension in order to study technically and financially interesting alternatives to conventional biological treatment - the "Pekilo" and "Anamet" methods — which both enabled the extraction of valuable byproducts. One argument used by MoDo while applying for extension was the current uncertainty regarding the timber situation which, according to the company, made it "indefensible" to invest about SEK 60 million in a biological treatment plant before the structural issues had been studied. The fact is that the board found it difficult to determine whether sulfite pulp production at Domsjö could be maintained and made profitable enough for the foreseeable future unless the conditions for the future supply of raw materials to the company's pulp mills could first be pinned down. The company had, with scanty results, tried to get its hands on the timber freed up when other Swedish mills were shut down.

The Finnish Pekilo method, which allowed a high-value protein for animal fodder to be produced from the wastewater, was the first method to be tested. The tests, carried out on a pilot scale, were successful but the method was abandoned due to the uncertain revenue opportunities for the protein. The Anamet method, whose main application had been wastewater treatment in the food industry, permitted the extraction of methane gas from wastewater. In the summer of 1981, the company approached AB Sorigona, which sold the Anamet method, and successful trials were thereafter performed on the wastewater in question. In October 1983, the MoDo board took the decision to allocate funds for a biological treatment plant using the recently developed Anamet method. Total investment cost was estimated at a hefty SEK 73 million (about USD 27 million in today's money 
value). The oil savings consequent upon the methane gas production were, however, at the same time estimated to a full $6,000 \mathrm{~m}^{3}$ per year, equivalent to a reduction in the mill's oil requirement by about 40 percent. Then in early 1985, the then biggest biological treatment plant in Sweden started at full capacity at Domsjö. According to prevailing environmental manager at Domsjö, the plant paid off at once due to the oil-savings.

\subsection{The License of 1989 and the Green Product MoDo Crown}

The deadline for the final conditions for discharges of bleach plant wastewater was postponed several times at the company's own requests and with the consent of the authorities to investigate opportunities to replace chlorine bleaching with another brightening process in order to reduce discharges. In the latter half of the 1980s and as an effect of the dioxin scare in the mid-1980s, the authorities further demanded the company to, in cooperation with SEPA, study the dispersion of chlorinated organic materials in bottom silt, sludge and wastewater. SEPA found the discharges of chlorinated organic substances from Domsjö to be considerably higher than they ought to be considering that the cooking process at Domsjö should have a much lower need for bleaching chemicals than the common kraft pulp cooking process." The reason for this must be investigated and the situation rectified as soon as possible." SEPA noted that this also required the development of the company's analysis techniques. In 1987, SEPA furthermore announced that extensive studies with regard to discharges from bleach plants now had shown that there was serious impact on fish even after relatively extensive measures and dilution. This indicated, SEPA argued, that bleaching with elementary chlorine must eventually "virtually" cease. Discharges from the bleach plant had thus grew into a troublesome issue for the company during the latter half of the $1980 \mathrm{~s}$, both with regard to the dioxin scare and the levels of chlorinated organic substances that were still being discharged and the impact/dispersion studies that the company had to mobilize.

In parallel to this development, the MoDo board experienced a situation of "psychological barriers" towards sulfite pulp among paper manufacturers, i.e., an ambition to get away from sulfite dependency even though the properties of sulfite pulp were satisfactory and its price was consistently lower than that for kraft pulp. This was a consequence from the halving of the number of sulfite mills in the world since the $1960 \mathrm{~s}$, where the sulfite pulp share of world trade pulp had been reduced from 35 to 15 percent. Among the world's sulfite mills, Domsjö was by far the largest manufacturer of bleached sulfite pulp intended for trade.

When the final emission limits for total organic chlorine finally was announced in 1989, they were set to an extremely low $1.0 \mathrm{~kg}$ per ton of pulp (from 1992 and onwards). At the same time, more rigorous standards were also set for BOD discharges; the limit for 1989 was set at 12.5 tons of BOD7 per day (including bleaching), and at 10 tons effective in 1991. The MoDo Board later established that conditions had been "seriously underestimated by the company." In order to meet the higher BOD standard for 1989, the company was forced to curtail operations at the sulfite mill for a period. The board further investigated whether an investment in an active sludge plant would be necessary in addition to the biological treatment plant. The serious situation demanded decisive and powerful action. Thus, in the fall of 1990, the company finally found a way to comply with the environmental standards process internally. An entirely new concept was developed; it was based on increasing the 
percentage of peroxide- and oxygen-bleached pulp and proportionately decreasing the percentage of chlorine dioxide-bleached pulp, in parallel with closing the bleach plant with counter-flow wash. The company board concluded that the concept created a platform that in the aftermath of the dioxin scare yielded the desired bright, chlorine-free and chlorine dioxide-free pulp with a better price picture than standard-grade kraft pulp. The bleach plant was rebuilt according to the new concept, whereupon the chlorine valve could be shut off for good. Through these measures, it became possible to close the bleach plant, and the discharges to water from this department stopped completely. Domsjö was in this way a pioneer both when it comes to the closed bleach plant and a chemical pulp brightened to the highest level of brightness without chlorine or chlorine dioxide. It is reasonable to assume that the company, while developing the new concept, had good use of its long standing history of in-house R\&D for the possibility of reducing the use of chlorine in the bleach process, such as with the oxygen bleaching technique. After a year on the market the company could furthermore establish that the chlorine-free pulp, the so-called MoDo Crown, "received a very good market acceptance", particularly in Great Britain and Germany. These were market advantages that had not been anticipated when the toxicity of chlorine first started to get investigated from an environmental point of view in the 1970s.

\section{Concluding Discussion}

In this article, we have explored the long-term experiences of business transforming towards greener production processes within the context of the Swedish institutional setting for environmental protection from the late 1960s to the 1990s. Our study shows that environmental issues became an integrated part of the business development at Domsjö/MoDo already in the early 1970s. To comply with new environmental standards, which became incrementally stricter during the studied period, the company was forced to not only invest in new technologies but also to develop new technology, underpinned by its in-house R\&D. At the core, in addressing the pollution problems, the ability to transform to enhance competitiveness while integrating far-reaching environmental improvements was developed. Thus, long-term goals and R\&D activities were coordinated between problems that were environmental in nature with activities aiming at production efficiency goals or new products. This progress was in turn heavily dependent on time and the development of new knowledge. In this context, the authorities practiced a flexible approach, which gave the company generous prohibition periods to find measures at economic feasible means. This enabled the company to develop and rebuild the processes and test and adapt new technologies, such as biological treatment technology enabling the extraction of valuable byproducts.

In the complex work to solve environmental issues, MoDo relied heavily on its in-house R\&D: a workforce sufficiently skilled to resolve process issues internally (in-plant) had been built up in the 1940s and 50s. This asset was central to the company given that there were no directly transferable technologies available to solve the specific process related problems at Domsjö. This was especially true for Domsjö, which unlike the lion's share of the Swedish pulp industry, produced sulfite pulp. The Swedish regulators in turn tried to avoid imposing specific technologies (standard based regulation), a regulatory approach criticized by the Porter hypothesis literature for inhibiting technological progress and innovation. The Swedish line was furthermore to deal with pollution problems by internal process changes instead of by end-of-pipe technology, which not least was expressed through the apology 
made by the Swedish EPA for deviating from this line while promoting biological treatment technology. Moreover, in addition to impacts of the flexible regulatory approach, authorities influenced the mill's adaptation process by both imposing challenging requirements and forwarding subsidies. The emission requirements imposed on the mill was challenging in the sense that there was no off-the-shelf technology to implement in order to reach the requirements, and they further hardened as the licensing process continued. In parallel, however, governmental subsidies to some part enabled the company to stepwise and partly meet the requirements. In the end, the governmental, partly flexible, partly challenging approach, in combination with the possibility of MoDo to rely on in-house R\&D and extensively advocate internal measures, brought about results in the true Porter "win-win" spirit.

Thus, the bio purification plant according to the Anamet method enabled both environmental improvements and energy savings, of oil, by 40 percent. The choice of the Anamet method was hence motivated by both environmental and economic reasons. Taking into account the challenging requirements concerning the discharges of $\mathrm{BOD}^{7}$ and the importance for the company to rely on in-house R\&D to find a solution, it is not likely that the company would have found an economically feasible solution in this matter without the extended prohibition periods granted by the environmental authorities. In essence, the regulatory flexibility to "time" enabled the firm to accomplish a solution with a "win-win" outcome, i.e., with both environmental and economic gains.

Challenging requirements along with extended prohibition periods, and a possibility for the company to rely on in-house $R \& D$, were in the same way central to the development of the first chlorine free pulp with highest brightness on the market, the MoDo Crown product: the dioxin issue had been raised in the mid-1980s whereby there was a growing market for the product. Thus, with this new product and related process change, the company not only achieved great emission cuts but also great market advantages. With a completely closed bleach plant, the company furthermore did not have to invest in an active sludge plant. This is a clear example of how environmental requirements can result in economic benefits and competitive advantages not known in advance, i.e., when the toxicity of chlorine first started to get investigated from an environmental point of view in the 1970s.

The long-term in-house R\&D activity on the bleaching process, which in the end would allow the launching of the unique MoDo Crown product, was initiated already in the 1940s and came at hand when the company in the late 1980s had to comply with strict requirements regarding emissions of both BOD and total organic chlorine. This case thus illustrates how it was a lot more than solely market demands behind the adaptation of Swedish pulp mills to chlorine free bleached pulp in the early 1990s: the ability to produce chlorine-free bleached pulp was based on knowledge and technology built up over many years and under incrementally increased regulative pressure. In addition, the focus on internal process changes was a prerequisite for this development.

These environmental regulation- and R\&D-related conditions were together very important for continuing the business in an uncertain economic situation: the survival of Domsjö was uncertain through the 1970s and 80s, mainly because of inconsistent wood supply and fluctuating market prices which endangered the company's financial situation. Central in explaining why Domsjö survived through this period, when many other sulfite mills did not, is however also the switch to the greener sodium base over calcium base made at the mill already in 1959.

Finally, focusing on environmental aspects in manufacturing we find two major points of importance. Firstly, the flexible regulatory approach was underpinned by a well-functioning dialogue 
between the regulator and polluter, and had an inherent respect for the time-consuming activity technology choice, which in turn was a prerequisite for the company to accomplish technology development and innovate. Secondly, the framing of the regulatory approach has long-term consequences for technological strategies chosen by firms; in this case, it enabled the company to develop and adapt solutions based on in-house R\&D and not on demands for standardized BAT. A flexible regulatory approach can thereby foster innovative solution that enables firms to not only stay in business, but also increase their competiveness. The most illustrating example from this study is the chlorine issue, where decades of investments in in-house R\&D on the bleaching process, partly under influence from a flexible but still challenging regulatory approach from the mid-1970s, explains why the company was able to respond rather quickly to the growing demand for chlorine-free paper at the turn of the 1980s with the unique MoDo Crown product. This also suggests that the regulatory approach explains why the Swedish pulp and paper industry became a market leader in chlorine free pulp technology, and thus reveals a more complex history than previously noticed.

\section{Acknowledgements}

Financial support was provided by the Kempe Foundations and Riksbankens Jubileumsfond (RJ), and is gratefully acknowledged. In addition, the authors wish to thank Holmen AB and its archive holder Brux for kindly letting us take part of the company archive.

\section{References}

1. Jänicke, M. Conditions for Environmental Policy Success: An international Comparison. The Environmentalist 1992, 12, 47-58.

2. Rajotte, A. Paper Production Technology and Environmental Performance in Sweden and Finland: Policy, Science and Market Share. Soc. Nat. Resour. 2003, 16, 719-728.

3. Smith, A.; Rajotte, A. When markets meet socio-politics: revisiting the introduction of chlorine free bleaching in the pulp and paper industry. In Technology and the Market: Demands, Users and Innovation; Coombs, R., Green, K., Walsh, V., Richards, A., Eds.; Edward Elgar: Cheltenham, UK, 2001; pp. 136-155.

4. Wallace, D. Environmental Policy and Industrial Innovation: Strategies in Europe, the US and Japan; Earthscan Publications: London, UK, 1995.

5. Palmer, K.; Oates, W.W.; Portney, P. Tightening Environmental Standards: The Benefit Cost or the No-Cost Paradigm? J. Econ. Perspect. 1995, 9, 119-132.

6. Porter, M.E. America's Green Strategy. Sci. Am. 1991, 264, 168.

7. Porter, M.E.; van der Linde, C. Towards a conception of the environment-competiveness relationship. J. Econ. Perspect. 1995, 9, 97-119.

8. Ambec, S.; Barla, P. Can Environmental Regulations Be Good for Business? An Assessment of the Porter Hypothesis. Energ. Stud. Rev. 2006, 14, 42-62.

9. Lanoie, P.; Patry, M.; Lajeunesse, R. Environmental Regulation and Productivity: New Findings on the Porter Hypothesis. J. Prod. Anal. 2008, 30, 121-128. 
10. Norberg-Bohm, V.; Rossi, M. The Power of Incrementalism: Environmental Regulation and Technological Change in Pulp and Paper Bleaching in the US. Technol. Anal. Strateg. 1998, 10, 225-245.

11. Requate, T. Dynamic incentives by environmental policy instruments-A survey. Ecol. Econ. 2005, 54, 175-195.

12. Fischer, C.; Parry, I.W.H.; Pizer, W.A. Instrument Choice for Environmental Protection-When Technological Innovation is Endogenous. J. Environ. Econ. Manag. 2003, 45, 523-545.

13. Pontoglio, S. An early assessment of the influence on eco-innovation of the EU Emissions Trading Scheme: evidence from the Italian paper industry. In Environmental Efficiency: Innovation and Economic Performances; Mazzanti, M., Montini, A., Eds.; Routledge: Oxford, UK, 2010; pp. 81-91.

14. Okereke, C.; McDaniels, D. To what extent are EU steel companies susceptible to competitive loss due to climate policy. Energ. Policy 2012, 46, 203-215.

15. Peterson, C. Finsk Ingenjörskonst Och Svenskt Imperiebyggande: En Jämförandestudie av Finsk Och Svensk Skogsindustri (in Swedish); SNS: Stockholm, Sweden, 1996.

16. Peterson, C. The Development Paths of Two Nordic Forest Nations, 1950-1992. Scand. Econ. Hist. Rev. 2001, 49, 23-41.

17. Melander, A. Industry-wide Belief Structures and Strategic Behaviour: The Swedish Pulp and Paper Industry 1945-1980. Scand. Econ. Hist. Rev. 2005, 53, 91-118.

18. Melander, A. Strategy Formation in the Swedish Forest Industry. Comparing SCA and Modo. In The Evolution of Competitive Strategies in Global Forestry Industries: Comparative Perspectives; Lamberg, J.-A., Näsi, J., Ojala, J., Sajasalo, P., Eds.; Springer: Dordrecht, The Netherlands, 2006; pp. 141-165.

19. Rennel, J. Långsiktigt värdeskapande och värdeförstöring. Analys av skogsindustrin 1975 med fokus på STORA (in Swedish); Handelshögskolan: Stockholm, Sweden, 2008.

20. Söderholm, K.; Bergquist, A.-K. Firm-collaboration and environmental adaptation. The case of the Swedish pulp- and paper industry 1900-1990. Scand. Econ. Hist. Rev. 2012, 60, 183-211.

21. Bergquist, A.-K.; Söderholm, K. Green Innovation Systems in Swedish Industry, 1960-1989. Bus. Hist. Rev. 2011, 85, 677-698.

22. Bergquist, A.-K.; Söderholm, K.; Kinneryd, H.; Söderholm, P.; Lindmark, M. Command-and-control revisited: Environmental compliance and technological change in Swedish industry 1970-1990. Ecol. Econ. 2013, 85, 6-19.

23. Gårdlund, T. MoDo 1940-1985; Mo och Domsjö: Örnsköldsvik, Sweden, 1986.

24. Hultman, S.; Johansson, M. Domsjö sulfitfabrik 90år. En bildkavalkad 1903-1993; Mo och Domsjö: Örnsköldsvik, Sweden, 1993.

25. Environmental manager at Domsjö sulfite mill in the 1970s and 1980s. Interview with Gustavsson R.; Östanå, Sweden, 14 June 2012.

26. Söderholm, K.; Bergquist, A.-K. Greening of Business: The Case of Domsjö Pulp Mill 1970-1990; Luleå university of technology: Luleå, Sweden, 2013.

27. Lundqvist, L.J. The Hare and the Tortoise: Clean Air Policies in the United States and Sweden; The University of Michigan University Press: Ann Arbor, MI, USA, 1980. 
28. Lundqvist, L.J. Miljövårdsförvaltning och Politisk Struktur (in Swedish); Uppsala University: Uppsala, Sweden, 1971.

29. Lundqvist, L.J. Sweden. In National Environmental Policies: A comparative Study of Capacity Building; Jänicke, M., Weidner, H., Eds.; Springer: Berlin, Germany, 1997; pp. 25-72.

30. Lindmark, M.; Bergquist, A.-K. Expansion for pollution reduction? Environmental adaptation of a Swedish and a Canadian Metal Smelter 1960-2005. Bus. Hist. 2008, 50, 530-546.

31. Melander, A. Industrial Wisdom and Strategic Change: The Swedish pulp and Paper Industry 1945-1990; Jönköping International Business School: Jönköping, Sweden, 1997.

32. Dahmén, E. Hur studera industriell utveckling? In Industriell Utveckling i Sverige. Teori och Verklighet Under ett sekel (in Swedish); Dahmén, E., Eliasson, G., Eds.; Research Institute of Industrial Economics: Stockholm, Sweden, 1980.

33. Dahmén, E. Development blocks in industrial economics. Scand. Econ. Hist. Rev. 1988, 36, 3-14.

34. Schön, L. En Modern Svensk Ekonomisk Historia: Tillväxt och Omvandling under två Sekel (in Swedish);Schön, L., Ed.; SNS-Center for Business and Policy Studies: Stockholm, Sweden, 2002.

35. Schön, L. En Modern Svensk Ekonomisk Historia. Tillväxt och Omvandling under två Sekel (in Swedish), 2nd ed.; SNS-Center for Business and Policy Studies: Stockholm, Sweden, 2007.

36. Official Statistics Sweden. Manufacturing (1961 and 1981); Statistics Sweden: Stockholm, Sweden, 1961, 1981.

37. Wohlfart, G. Svensk Skogsindustri i Omvandling: Utvecklingen Sedan 1950, Part 1 (in Swedish); The Cooperation Committee of the Forest Industries (Skogsindustriernas samarbetsutskott), Strukturutredningen, Grafikon AB: Stockholm, Sweden, 1971.

38. Wohlfart, G. Svensk Skogsindustri i Omvandling: Utvecklingen Sedan 1950, Part 2 (in Swedish); The Cooperation Committee of the Forest Industries (Skogsindustriernas samarbetsutskott), Strukturutredningen, Grafikon AB: Stockholm, Sweden, 1971.

39. SSVL (Swedish Forest Industries' Water and Air Pollution Research Foundation). SSVL 74-85: Miljöskyddskostnader inom Svensk Skogsindustri 1985 t o m 1991 (Environmental protection costs in the Swedish forest industry 1985-1991, Appendix 2 and 20); Report available on CDROM disc at the Swedish Forest Industries: Stockholm, Sweden, 1989.

(C) 2013 by the authors; licensee MDPI, Basel, Switzerland. This article is an open access article distributed under the terms and conditions of the Creative Commons Attribution license (http://creativecommons.org/licenses/by/3.0/). 